\title{
Title: The Impact of Digital Transformation for Social Enterprise
}

Author: Reine Yolite Simpadjo

\begin{abstract}
:
Nowadays most people remain connected via social media networks. This is a highly lucrative and expansive market for social enterprises to penetrate and evaluate the buying patterns of customers so that they can provide customized user experiences. Digital transformation provides countless advantages and options, including improved inventory management, detailed insights, enhanced real-time customer interaction, higher productivity, reliable forecasting, dependable business decisions, improved resourced allocation, and real time interaction with customers. All this is too good for modern enterprises to pass up. This sort of technology and innovation, when coupled with digital business, lends support to the digital transformation of a company, providing it with the requisite degree of competitive advantage. Digital transformation helps businesses meet the demands of the changing digital economy. Also with the help of digital transformation, companies are finally able to go paperless. This process lowers costs and safeguards the environment. So with lots of this social enterprises in Asia that use or participant in digital transformation it can help them to meet customer expectation soon, and digital transformation is cost effective when social enterprises profits, the community or the society profits.
\end{abstract}


I. What is a social enterprise? What types of social enterprises in Indonesia? (see Pratono et al 2019). Draw distinction between social enterprise for community development in Indonesia and Taiwan! See Pratono \& Wong (2019).

A social enterprise is a commercial organization that has specific social objectives that serve its primary purpose. Social enterprises seek to maximize profits while maximizing benefits to society and the environment. Their profits are principally used to fund social programs.

In Indonesia, social enterprises have emerged from community organizations, including religious groups and professional organizations. The Indonesian political context also plays an important role in the dynamics of the evolution of the third sector, including social companies. The phenomenon of the emergence of social companies in Indonesia became clear during the transition from authoritarian regimes to democratic regimes. Social entrepreneurs in Indonesia also pursue purely social missions, they have different motives ranging from personal values, social norms, to religion. There are four models of social enterprises in Indonesia:

1. Entrepreneurial NPO model. A social company was established with a strong philanthropic orientation. They try to develop business activities to support their social activities. The purpose of this organization is for social mission and economic activities such as create jobs for the neighbours and society. In Indonesia, SMEs have a very important role in terms of the number of business units and job creation.

2. Social cooperative (SC) model. Social enterprise originates from the transfer of cooperatives or other types of mutual interest organizations with a concern in more general interests. This organization not only focus on provides donation but also establishing partnership with local communities in need of logistic support.

3. Community development enterprise (CDE) model. Social enterprise focusing on local economic development in a specific area. The business division was established to gain access to market opportunities for the products from the community development program. This organization's mission is tried to solve the problems of their community. The achievements of this organization such as positive social change and promoting social equity

4. Social business (SB) model. Social enterprise resulting from organizations with a strong market capability establishing a social division. In Indonesia, this type of social enterprise operates under the legal form of companies or for-profit organizations to gain credibility with their business partners. SE belonging to this model can be franchised entities of social enterprises from abroad and have a strong orientation toward the international market.

In general, most social enterprises in Indonesia choose a non-profit model and register under the legal form of foundations, associations or cooperatives. The majority of organizations observed using their entrepreneurial activities as a means to fund their social programs. 
There are 9 criteria social enterprise for community development in Indonesia and Taiwan

1. Products. In Taiwan, tourism business was used as the main strategy to generate income for the community, however in Indonesia, they started from microfinance and then expanded into a tourism business

2. Economic risk. For the economic risk Taiwan, project very dependent on uncertain market so sometimes their income it's not stable. And for Indonesia to avoid the default the SE create social capital for lending groups and local communities for they can survive and still pay the loans.

3. Paid workers. In Taiwan they paid school instructors part time salaries but in Indonesia the microfinance members are full-time staff, but for tourism business they hired part-time staff.

4. Social benefit. In Taiwan the economic activities become the main activities to gain money to get education, and health services so in Taiwan there is microfinance to help economy. But in Indonesia, the microfinance project to provide financial services for poor families and for the tourism business pushed for the environmental movement or go-green.

5. Founders. In Taiwan the founders involved with local leaders and a stakeholder for their project, which is means the government also take control of the community. But in Indonesia, a woman's group was the founder of the microfinance and then they push community to build environmental tourism business.

6. Profit distribution. In Taiwan mostly their income from tourism industry they donate to education service but in Indonesia the community members agreed that $15 \%$ of their revenues from microfinance project they donate for social projects.

7. Autonomy. In in Taiwan there is relationship between communities, universities, and the stakeholders to always doing the project together, but in Indonesia they run the community depends on other organizations support to run the project, but these organizations do not manage the community development enterprise

8. Ownership. In Taiwan the community owned by the local communities and also stakeholders so there's no private organizations but in Indonesia the community owned by only the village community so the local government or government don't control of that community.

9. Participatory dimension. In Taiwan the negotiation become very usual to take decision for some issue, different groups, instructors and other stakeholders also took part in the process. But in Indonesia the annual meeting was held to encourage villagers' participation in the decision making process.

In conclusion, the main difference between Indonesia and Taiwan is: in Indonesia, official reports are used as acting to gain trust from the public, although financial reports are a challenge for villagers. Whereas in Taiwan, oral distribution is used to report every measure of education, community support projects, and to get support from villagers 
II. Find a course from Coursera.org, which is relevant for the class of business and economics in Asia! Please provide your argument, why it is relevant!

Digital transformation is a transformation from business. This method of transformation is different from the others, because digital transformation only refers to changes made using digital technology as a pillar. Digital transformation is a process part of a larger technology, and this is a change related to the application of digital technology in all aspects of life that exist in society. In this article/video that I find in Coursera, they talk about digital transformation in two ways. First they discuss the pace of change and the imperative it creates for businesses. Next they provide the context for this transformation and what it takes to win in the digital age. And then they discuss about BCG's proprietary framework, which provides a practical strategic model for moving from a legacy to a digitized business. In this video also explain the framework's fundamental duality and the different enablers of digital transformation. Which is helps me to identify key areas to digitize, including strategy, core processes, and technology.

The transformation phase means that the inherent use of digital enables new types of innovation and creativity in certain domains, not just to improve and support traditional methods, such as changes in marketing strategies, business models, operations, products, marketing approaches, objectives and others that are all connected to digital matters. Like changes in marketing strategies that now use social media more than advertisements in print media, and others. Some meanings of digital transformation also refer to paperless or no use of paper anymore. Like companies that implement the absence of printed files or companies that change from book printing to digital book publishing companies or e-books.

Digital transformation has a big influence among businesses like, for hospitality businesses like hotels and others, it has become one of the positive and negative ones. Positive, with the existence of digital transformation, they can make prospective customers easier to book rooms or make reservations about various other things easily. While the downside, their rivals are increasing. Not infrequently, there are those that make prices so much cheaper and now there are many low-priced hotels that have quite good facilities. There are five digital technologies that have been the basis of digital transformation since 1990, namely:

1. Mobile

2. Social

3. Cloud

4. Big Data

5. Unified Communications.

The trend that has the biggest impact on digital transformation today is cloud because it offers unlimited access to capabilities. Anyone or anyone can access not only information but also storage, not just processing capabilities, now we all have access to all the technology around us. When you have freedom of access, it provides a broad opportunity to create new business models. However, if you look ahead, there are 6 technological trends that can affect the next shift in how we improve customer experience, improve what we do at work, change products and utilize machines as needed for augmented humanity: 
1. IoT

2. 3D Printing

3. Augmented Reality/Virtual Reality

4. Robotics

5. Block Chain Technology

6. Artificial Intelligence/Cognitive.

Digital transformation is not only about change and innovation, but also about how this technology is adopted and used. This of course brings benefits to companies, Digital Transformation so relevant to create in Asia, because many big company now days also try to apply the digital transformation. Because, the main driver of digital transformation is profitability, customer satisfaction, and increased market reach. In the context of digital business transformation, aspects such as business functions, processes, activities, assets, and models are interconnected. Digital transformation is also able to increase worker empowerment. That is, employee performance becomes more effective and efficient, such as the ability to work anywhere and anytime, expand and improve the communication process, and the ability to share knowledge competently.

So that's why this is Digital transformation so relevant in Asia because, in Asia there are so many companies, and business leaders must constantly encourage their organizations to ensure that these changes can significantly increase productivity while providing an exceptional customer experience. Digital transformation is once again not just the application of technology in organizational activities. But how can the organization be able to change and develop at each level of its organization through technology so as to achieve the results it wants to achieve. That is why we need to understand and start digital transformation especially in Asia because there are many benefits that you can get if you understand it well. 


\section{Reference}

Pratono, Pramudija, Sutanti (2019). Social enterprise in Indonesia: Emerging models under transition government, Bidet \& Defourny (ed), Social Enterprise in Asia: Theory, Models, and Practice, London: Routledge

Pratono \& Wong (2019). Social enterprise for rural community development: Lesson from two case studies in Indonesia and Taiwan, Bidet \& Defourny (ed), Social Enterprise in Asia: Theory, Models, and Practice, London: Routledge

Social Enterprises UK. (n.d.). What is it all about? https://www.socialenterprise.org.uk/what-is-it-all-about

Barone, A. (2019). Social Enterprise. USA: Investopedia. https://www.investopedia.com/terms/s/social-enterprise.asp

Lenox, M., Dannouni, A., Rueger, S., \& Ong, C. F. (2019). Digital Transformation.: Coursera https://www.coursera.org/learn/bcg-uva-darden-digital-transformation 